\title{
没水球体に作用する二成分波の波力の特性 \\ WAVE FORCES ACTING ON A SUBMERGED SPHERE DUE TO TWO-COMPONENT COMPOSITE WAVES
}

\author{
岩田好一朗*·水谷法 美**・都築 克 嘉*** \\ By Koichiro IWATA, Norimi MIZUTANI and Katsuyoshi TSUZUKI
}

\begin{abstract}
This paper is to discuss experimentally the wave forces acting on a submerged sphere in the two-component composite wave field. The measured wave forces are decomposed into the drag and inertia forces using the Morison's formula. The maximum wave force, the drag and inertia coefficients of individual waves defined by the zero-downcrossing method are mainly investigated in the relation to those of regular waves. Time variations of the water surface profile have significant effects upon the characteristics of the wave forces. The maximum wave force and inertia coefficient of the successive waves whose heights are increasing are shown to be larger than those of the successive waves whose heights are decreasing. Their variations become larger as the difference of the successive wave heights become larger.

Keywords: wave force, sphere, drag and inertia coefficients, two-component composite wave
\end{abstract}

\section{1. 緒 言}

近年, 海岸・海洋空間に対する関心が高まりつつあり, 海岸・海洋空間の高度利用, あるいは, 静穏域の拡大が 望まれるようになった. それに伴い, それらの空間を制 御したり, あるいは, 利用するための構造物の多様化が 進むことが予想される. 従来の構造物とは異なり, 今後 の構造物に特に期待されるのは, その機能だけでなく, 水質の保全, 景観の問題に代表されるような, 環境の面 からの要求を満たすものであろう.こういった要求を満 たすための 1 つの構造様式として, 構造物を静水面下に 潜らせた没水式の構造物があり, 今後, 没水型の構造物 の需要が大きくなることが予想される. 本研究は, 構造 物の形状として球体を取り上げる. 没水型の構造物に作 用する波力は, 静水面上に出ている構造物に比べて一般 に小さくなるが, 逆に, 静水圧は大きくなる. 球体は, 等方性を有する水圧に対して最も有利な形状であり，た とえば, 海中備蓄タンク, 浮体構造物の係留の中間ブイ

* 正会員 工博 名古屋大学教授 工学部土木工学科 ( ₹464-01 名古屋市千種区不老町)

** 正会員 工博 名古屋大学助手 工学部土木工学科 (同上)

*** 正会員 エコー(株) 第 1 技術部数理解析課 ( ₹116 荒川区南千住 1-59-7)
なよ゙のように球状構造物の必要性が考えられる. 著者ら は, 波動場に置かれた没水球体に作用する波力について 検討を加えてきた1). そして, 規則進行波中の波力に対 しては, Morison 式の適用範囲, 波力係数の特性など を明らかにしてきた。ししし, 実際の海洋での波浪は不 規則であるため, 不規則波による波力の特性について明 らかにしておくことが重要である. 球体に作用する不規 則波力の研究は非常に少ない. Iwata et al. ${ }^{2)}$ は, 不規則 波の波力は, 慣性力が支配的である場合は水位変動から 予測することが可能であること, また, 不規則波の波力 係数は, 規則波に対する値に比べて小さくなる傾向があ ることを指摘した. しかし, 波力係数が小さくなる原因 については明らかにされておらず，検討の余地が残され ている.

不規則波は，2つ以上の自由波から構成される波とし て定義することができるため，2つの自由波から構成さ れる二成分波は, 不規則波の最も簡単な形の波であると 考えられる. したがって, 複数の自由波からなる不規則 波の波力の機構, および 1 つ自由波からなる規則波と の波力の差異を明らかにするうえで，2つの自由波から なる二成分波の波力の特性を明らかにすることは基本的 に重要である. 本研究では, 没水球体に作用する二成分 波の波力の特性について, 水理実験を詳細に行い, 前後 
の波の波高の相関に代表されるような波の時系列特性が 波力に及ぼす影響について議論するとともに，その機構 についても検討を加える. そして，二成分波の波力を規 則波の波力と比較しながら波の不規則性が波力に及ぼす 影響について議論しようとするものである.

\section{Morison 式と次元解析}

\section{(1) Morison 式 ${ }^{3)}$}

一般に，物体の代表径が入射波長に比べて小さく，波 の変形が無視できる場合には, 物体に作用する波力は, Morison 式で算定されることが多い，後述するように， 本研究で取り扱う球径が入射波長に比してきわめて小さ いので，球体に作用する波力を Morison 式で表わすも のとする. そして, 同式中の波力係数の特性について検 討を加える. 球体に作用する $x$ 方向， $z$ 方向の波力 $F_{x}, F_{z}$ に Morison 式を適用すると，それぞれ次のよう に表わされる.

$$
\begin{aligned}
& F_{x}=\frac{1}{8} C_{D X} \rho \pi D^{2} u \sqrt{u^{2}+w^{2}}+\frac{1}{6} C_{M X} \rho \pi D^{3} \dot{u} \\
& F_{z}=\frac{1}{8} C_{D z} \rho \pi D^{2} w \sqrt{u^{2}+w^{2}}+\frac{1}{6} C_{M Z} \rho \pi D^{3} \dot{w}
\end{aligned}
$$

ここに, $C_{D X}$ と $C_{D Z}$ は抗力係数, $C_{M X}$ 之 $C_{M Z}$ は慣性力係 数, $\rho$ は水の密度, $D$ は球の直径, $u, w$ はそれぞれ水平. 鉛直方向の水粒子速度であり，上付きドット（・）は時 間に関する微分を示す。なお， $x$ は波進行方向を正の向 きとする水平軸, $z$ は静水面上に原点をもち, 鉛直上向 きを正とする鉛直軸である.

\section{(2) 次元解析}

本論では，二成分波の波力の特性を，まず，ゼロ・ダ ウンクロス法で定義された一波ごとの波（本論では，波 別解析波之称する) を取り上げ，波別解析波の波力の特 性を中心に議論する。これは，波別解析波と同じ波高， 周期をもつ規則波の波力と比較するうえで重要であるか らである. 波別解析波の波力 $F$ は, 次に示される 11 個 の物理量によって支配されると考えられる。

$$
F=\phi(U, D, d, h, T, \mu, g, \rho, \gamma, \delta ; t) \cdots
$$

ここに, $U$ は流速の振幅, $d$ は静水面から球の中心ま での距離， $h$ は静水深， $T$ は波別解析波の周期， $\mu$ は水 の分子粘性係数, $g$ は重力加速度, $\gamma$ は前後の波の波高 の相関係数， $\delta$ は波高の変動係数， $t$ は時間である. 二 成分波を取り扱うため, 式（3）には，本来ならば $2 つ$ の自由波の振幅 $\left(a_{1}, a_{2}\right.$, 添字 1,2 は 2 つの自由波を示 す）之周期 $\left(T_{1}, T_{2}\right)$ が考慮されるべきであるが，これ らの値は, 二成分波の包絡の周期とその形状を与えるも のであり, $\gamma$ と $\delta$ に密接に関係する量である. 本論では, 二成分波を不規則波の 1 つとして定義するため，不規則 波への適用も考慮して, 本研究では, $a_{1}, a_{2}, T_{1}, T_{2}$ の
代わりに $\gamma$ と $\delta$ を取り上げる。なお， $\gamma, \delta$ はそれぞれ 次式で与えられ，規則波の場合は， $\gamma=1, \delta=0$ となる.

$$
\begin{aligned}
& \gamma=\frac{1}{N-1} \sum_{i=1}^{N-1}\left(H_{i+1}-\bar{H}\right)\left(H_{i}-\bar{H}\right) / \frac{1}{N} \sum_{i=1}^{N}\left(H_{i}-\bar{H}\right)^{2} \\
& \delta=\left\{\frac{1}{N} \sum_{i=1}^{N}\left(H_{i}-\bar{H}\right)^{2}\right\}^{1 / 2} / \bar{H}
\end{aligned}
$$

ここに, $H$ は波高, $\bar{H}$ は平均波高, $N$ は波の数で, 添 字 $i$ は $i$ 番目刀波を示す. また，二成分波の波別解析波 の周期 $T$ は, 同一の波の中ではほぼ等しいため, $T$ の 代わりに平均周期 $\bar{T}$ を採用することにする.

式（3）を無次元表示すると式（4）を得る.

$$
\frac{F}{\rho U^{2} D^{2}}=\Phi\left(\frac{U \bar{T}}{D}, \frac{U D}{\nu}, \frac{h}{g \bar{T}^{2}}, \frac{D}{h}, \frac{d}{h}, \gamma, \delta ; \frac{t}{\bar{T}}\right)
$$

ここに, $\nu(=\mu / \rho)$ は水の動粘性係数である. 式 $(6)$ の右辺第 1 項の $U \bar{T} / D$ は, Keulegan and Carpenter 数文 (以下, K. C. 数と略記する), 第 2 項の $U D / \nu$ は Reynolds 数 (以下, $R e$ 数之略記する), 第 3 項は水深 波長比に相当する項, 第 4 項は球径水深比, 第 5 項は相 対設置水深, である. 波力については, その最大値 $F_{m}$ (添 字 $m$ は波別解析波ごとの最大値を示す) に着目する場 合は， $t / \bar{T}$ とは独立とみなすことができる。

Morison 式中の波力係数も波力之同様に式（6）の 右辺に示される無次元量によって支配されると考えられ る.ただし，波力係数を時間と独立した量として取り扱 うため, $t / \bar{T}$ とは独立である. 本研究では, 次章で詳 述するように, 波力係数を波別解析波ごとの值のほかに, 1 つの波の時系列記録内では一定の值であると仮定して 得られる值も計算した.この場合の波力係数は，Uを 時系列を代表する流速の振幅とすることにより, 波別解 析波に対する值と同じ無次元量によって支配されると考 えられる。

以上の結果に基づいて, 波力の特性, 特に波力係数を 式（6）の無次元量と関連づけながら論議するものとす る.

\section{3. 水理実験}

\section{（1）実験方法}

実験は, 名古屋大学工学部土木工学科の二次元鋼製水 槽（長さ $25 \mathrm{~m}$, 高さ $0.95 \mathrm{~m}$, 幅 $0.7 \mathrm{~m}$ ) で行われた. 水槽の一端には, フラップ型不規則波造波装置が設置さ れている，他端には，反射波を極力小さくするために， 消波ブロック，捨石，およびウレタンメッシュから構成 される消波装置を設置した．球体に作用する波力の算定 に際して，Proximity Effect なざで Morison 式が適用 できない範囲があることが著者らによって明らかにされ 
ているので1)，本研究では，二成分波による波力の基本 的な特性を議論するため, 主に Morison 式の適用可能 な範囲を対象として実験を行った．実験条件を，以下の ように決めた. 球の直径を $2.5 \mathrm{~cm}$ とし, 静水深を 3 種 類 $(h=70,56,40 \mathrm{~cm})$ 変化させ, 球の設置水深 $(d)$ を $h=70 \mathrm{~cm}$ に対しては $d=0.179 h, 0.357 h$ の 2 種類, $h=56 \mathrm{~cm}$ に対しては $d=0.357 h, h=40 \mathrm{~cm}$ に対して は $d=0.357 h, 0.425 h$ の 2 種類とした。二成分波は， 2 台の信号発生装置から出力される周期の異なる 2 つの 正弦信号を重社合わせ，それを入力とすることにより生 起させた. 2 つの正弦信号の周波数は，0.6，0.7，0.8， $0.9,1.0,1.1 \mathrm{~Hz}$ から得られる 15 種類の組合せである. 実験では，2つの正弦信号の振幅を同じ值に保ちながら 合成波の最大波高が 10～20 cm になるように振幅を 2 4 種類変化させた. 実験種目は全部で 146 ケースであり, すべてのケースで水位変動 $\eta$, 流速 $u, w$, および波力 $F_{x}, F_{z}$ を同時に計測した。 なお，水位变動を電気容量 式水位計で, 流速を電磁流速計で, 波力を Cantilever 型波力計 ${ }^{2)}$ で計測した. 波力計の固有振動周波数は約 15 $\mathrm{Hz}$ であり，入射波の周波数に比べて十分高いので計測 波力に及ぼす固有振動周波数の影響はほとんどない。ま た，波力計の検定結果より，入力と出力の間には十分な 線形性が確認されている。計測時間は, 各ケースとも約 2 分間とし, 計測された水位, 流速, 波力の時間波形は すべて磁気テープとペン書レコーダーに記録され，解析 に使用された。

また，波力の特性をより詳細に議論するため，適当な ケースについて, コンデンスミルク法により, 球体周り の流況の可視化実験を行った. 実験で得られた流況はビ デオカメラ (30 コマ/秒) に記録され, 解析に使用され た.

\section{(2) 解析方法}

実験で得られた水位，流速，波力の時間波形をすべて サンプリングタイム 0.05 秒で離散化し，解析に使用し た．解析に使用したデータの個数は 1024 個（51.2 秒に 相当）である。これらのデー夕を使って式（6）中の無 次元量を波別解析波ごとに計算した。ただし，二成分波 では, 流速の振幅は時間的に変化するため, 流速の振幅 の代わりに波別解析波ごとの流速の rms 值を採用し， さらに, 規則波との関連を考慮して本研究では $x, z$ 方 向の流速の振幅としてそれぞれ $\sqrt{2} u_{\mathrm{rms}}, \sqrt{2} w_{\mathrm{rms}}$ を採 用した。したがって，たとえば K.C. 数については， $x$ 方向は $\sqrt{2} u_{\mathrm{rms}} \bar{T} / D, z$ 方向は $\sqrt{2} w_{\mathrm{rms}} \bar{T} / D$ となる. なお，本研究では，波別解析法はゼロダウンクロス法を 採用した。 また，式（1)，（2）に示される Morison 式中の波力係数も計算した. 波力係数の計算方法は, 最 小二乗法 ${ }^{2}$ を採用した。この際, 波力係数は, 以下に示
される 2 通りの手法により，2 種類の値を計算した。

（i） 波力係数は,波別解析波ごとに異なると仮定し， 波別解析波ごとに波力係数を計算する.

（ii）波力係数は，1つの時系列記録内では一定であ ると仮定し，1つの二成分波に対して一組の波力 係数を計算する.

なお，（ii）の手法で計算された波力係数は，（i ）の手 法で計算された波力係数と区別するため，上付きバ一 (一) をつけて示す.

本研究では, まず, （ｉ）の手法で得られた結果を使い， 波別解析波と同じ周期，波高をもつ規則波と比較した場 合に，波力係数が，規則波と二成分波とでどのような差 異があるのかを検討する．ついで，（ii）の手法で得ら れた結果を（i ）の手法で得られた值と関連づけながら, 二成分波の波力の時間波形の水位変動からの予測につい て検討を加える．なお，波力を計算するうえで必要な加 速度の時間波形は，流速の時間波形に数值微分に相当す る数值フィルターをかけることにより計算した ${ }^{1,2)}$. 流 速之加速度の時間波形は，3 次のオーダーまでの範囲に 対する規則波の理論值と実験值の比較を行い，十分な精 度をもつことを確認している。

球体周りの流況の詳細については，ビデオカメラで撮 影された流況をコマ送り再生させて求めた.

\section{4. 実験結果とその考察}

\section{（1） 慣性力係数の特性}

$\gamma$ の值は，2つの成分波の周期，振幅の組合せによっ て変化する.このため, $\gamma$ による影響を検討するために, $\gamma$ の值を次の 4 つの領域，すなわち，(A) $0.5 \leqq \gamma<1.0$, (B) $0.0 \leqq \gamma<0.5$, (C) $-0.5 \leqq \gamma<0.0$, (D) $-1.0 \leqq$ $\gamma<-0.5$, に分けて考察するものとする.この $(\mathrm{A}) \sim(\mathrm{D})$ の領域のうち, (A) と (C) の領域に対する水位変動, 流速, 加速度, 波力の時間変動の代表例を図一1に示す. ただし，1つの時系列内での最大值（添字 $\max$ で示す） により，それぞれ無次元化してある．同図より， $\gamma$ の值 が小さくなるとビートの周期が短くなり，引き続く波の 波高の差が大きくなるのがわかる．本研究では，まず， 慣性力係数の特性を議論する.

a) $C_{M X}$ (波進行方向の慣性力係数)

図一1 は, 慣性力が圧倒的に卓越する場合の波力の時 間波形を示したものであるが，無次元加速度と無次元波 力を比較すると, 波高が増大する過程 (以後, 波高増大 過程と称する) の波では無次元波力の方が無次元加速度 よりも大きく, 逆に, 波高が減少する過程 (以後, 波高 減少過程と称する）の波では, 無次元加速度の方が無次 元波力よりも大きくなる傾向が認められる。これは, 慣 性力が卓越する場合の一般的な傾向であり，加速度に対 


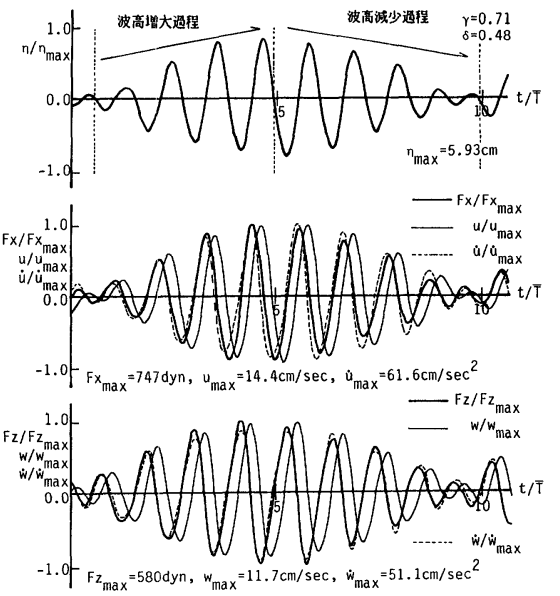

(a) $\gamma=0.71\left(1.1 \leqq \sqrt{2} u_{\mathrm{rms}} \bar{T} / D \leqq 8.2\right)$
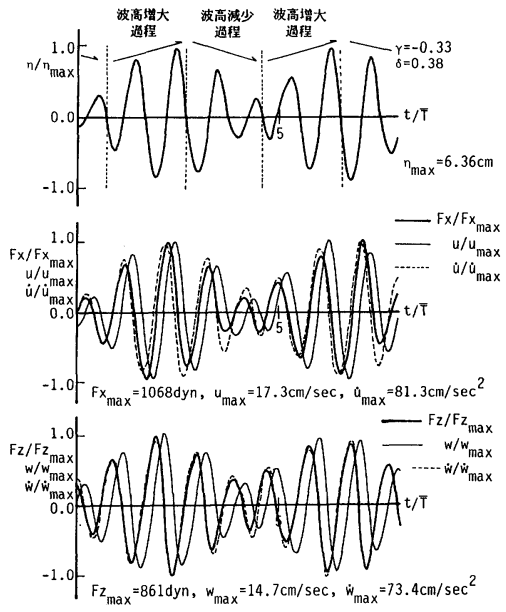

(b) $\gamma=-0.33\left(1.6 \leqq \sqrt{2} u_{\mathrm{rms}} \bar{T} / D \leqq 7.8\right)$

図一1 水位, 流速, 加速度と波力の時間波形

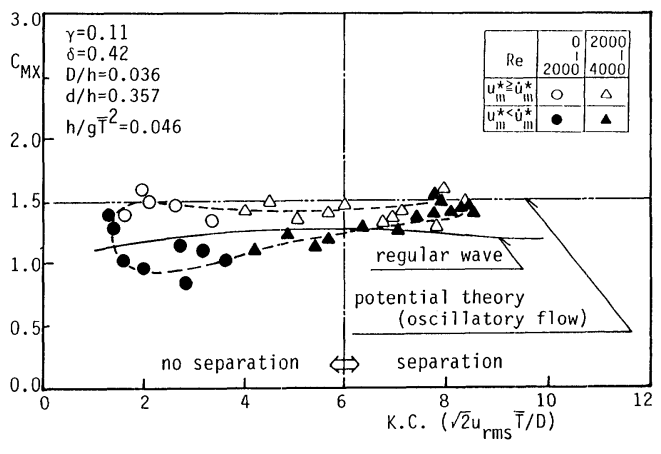

図一2 $C_{M X}$ と K.C. 数の関係 (慣性力が卓越する場合)

する波力の大きさが波高減少過程より波高増大過程の方 が大きくなること，すなわち，波高減少過程よりも波高 增大過程の方が, 慣性力係数は大きくなることを示す. この原因，および機構について以下に議論する.

\section{a-1) K. C. 数之 $R e$ 数の効果}

図一2 は, $C_{M X}$ と K. C. 数の関係を示した一例であり, 剝離の始まる K. C. 数の值も同時に示してある. また, 図中の破線は実験値の分布の概略を結んだ線であり，比 較のために著者らによって得られた規則波に対する $C_{M X}{ }^{1}$ も示されている. 実験によると, 波別解析波の $C_{M X}$ は, 全体的には振動流中に置かれた球体に対するポ テンシャル理論值 $1.5^{5)}$ より若干小さくなる，そして， 同じ K. C. 数の值に対して 2 つの值をとり, 波高増大 過程の波の值が大きな值に, 波高減少過程の波の值が小 さな值になり，剝離のない領域で特に明瞭なループ状の 分布をすることが一般的な傾向として認められた。すすな わ与, 二成分波の波別解析波の $C_{M x}$ は, 波高増大過程 のときにループの上側の值，つまり大きな值を，波高減
少過程のときにループの下側の值，つまり小さな值をと りながら，ビートの一周期でループを一周する.

図一1 からも認められるように，波高増大過程では， 無次元加速度の最大值 $\left(\dot{u}_{m}^{*}\right)$ よりも無次元流速の最大 值 $\left(u_{m}^{*}\right)$ の方が全体的に大きく, また, 波高減少過程 では， $u_{m}^{*} よ り も \dot{u}_{m}^{*}$ の方が全体的に大きくなる傾向が ある.すなわち，波高増大過程と波高減少過程では，加 速度と流速の相対的な大きさが異なる．そこで， $C_{M X}$ に 及ぼす流速，加速度の相対的な大小関係の影響を調べる ために，図一2では， $u_{m}^{*} か ゙ ~ u_{m}^{*}$ よりも大きい値を白抜き の記号で，逆に， $u_{m}^{*} よ り も ~ \dot{u}_{m}^{*}$ の方が大きい值を黒塗 りの記号で示してある. 同図にも示されているように， 明らかに $u_{m}^{*}$ の方が $\dot{u}_{m}^{*}$ よりも大きい波の $C_{M x}$ の方が, $u_{m}^{*}$ よりも $\dot{u}_{m}^{*}$ の方が大きい波の值よりも大きく，波高 の大小関係ではあまり明瞭でなかったビートの谷と峰の 波の值についても $u_{m}^{*}$ の方が $\dot{u}_{m}^{*}$ よりも大きい波の方が $C_{M X}$ は大きくなることがはっきりわかる.さらら， $u_{m}^{*}$ と $\dot{u}_{m}^{*}$ が等しい規則波の值と比較すると， $u_{m}^{*}$ の方が $\dot{u}_{m}^{*}$ よりも大きくなる波の值は規則波の值よりも大きく， $u_{m}^{*}$ が $\dot{u}_{m}^{*}$ よりも小さくなる波の值は規則波の值よりも 小さくなる傾向が認められる，なお，ビートの峰と谷の 波の一部を除けば，波高増大過程の波と $u_{m}^{*}$ が $\dot{u}_{m}^{*}$ より

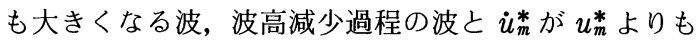
大きくなる波の対応は非常によいため, 本論では, 以後, 波高増大過程の波，波高減少過程の波の定義は，それぞ れ $u_{m}^{*} \geqq \dot{u}_{m}^{*}, u_{m}^{*}<\dot{u}_{m}^{*}$ 亡する.

$C_{M X}$ の波高増大過程と波高減少過程の差の原因を次の ように考えることができる. Re 数が 2000 以下の值 $(\bigcirc$ 印）と 2000 以上の値 $(\Delta$ 印) を比較すると，明らかに $R e$ 数の小さい方が慣性力係数の值の差が大きいことが 


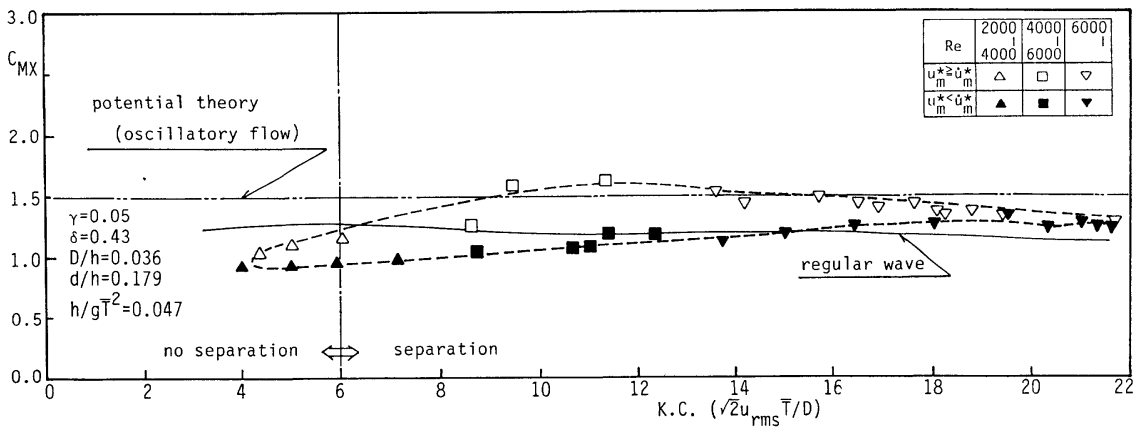

図一3 $C_{M X}$ と K. C. 数の関係（抗力が卓越する場合）

わかる.これは，粘性が慣性力係数の值に影響を及ぼし ていることを示す結果である．剝離のない範囲では，水 の粘性による球体表面での摩擦力之直立円柱に対して指 摘されているような境界層の発達のための運動量の欠損 による力 ${ }^{6}$ が抗力の重要な成分であると考えられる. 水 平床での底面摩擦力については, 層流状態では摩擦力の 位相は流速の位相よりも $\pi / 4$ だけ先に進むことが報告 されている7). また，波動場中の直立円柱表面に形成さ れる境界層内の流速も, 主流に比べて位相が先に進むこ とが報告されている8 . 同様に, 波動場におかれた球体 表面でも摩擦力の位相が流速の位相より先に進むと仮定 すれば，球体に作用する波力を Morison 式で算定する 以上は，摩擦力は慣性力にも含まれることになる．また， 運動量欠損に伴う抗力にも加速度と同位相になる成分が 含まれている ${ }^{6)}$. 球表面での摩擦力が慣性力にも含まれ るならば，同じ加速度の波であっても相対的に流速が大 きい波高増大過程では波高減少過程より慣性力に含まれ る摩擦力は大きくなる. また, 運動量欠損による抗力も, 円柱に対する表示式 ${ }^{6}$ によると波高増大過程の方が大き くなることになり, そのため, 波高増大過程の慣性力が 波高減少過程の慣性力よりも大きくなったものと考えら れる.K. C. 数が同じ波ならば，波高増大過程の波と波 高減少過程の波では流速は等しいため, 慣性力に含まれ るこれらの抗力の影響は同じ程度であると考えられる. しかし, 慣性力係数を計算する際に除数となる加速度は, 波高増大過程の波の方が小さいために，加速度に対する 抗力の割合は, 波高増大過程の波の方が大きくなる.し たがって，波高増大過程の $C_{M X}$ が波高減少過程の波の 值よりも大きくなったものと考えられる．また，波別解 析法による見掛けの差も含まれている可能性もあるが, 少なくとも，ゼロダウンクロス法とゼロアップクロス法 による差異はないことを確認している。

図一3 は，K．C. 数が比較的大きく抗力が卓越する場 合の $C_{M X}$ と K. C. 数の関係を図一2 と同様な方法で図示 したものである. 図一2ではあまり明瞭ではなかったが,

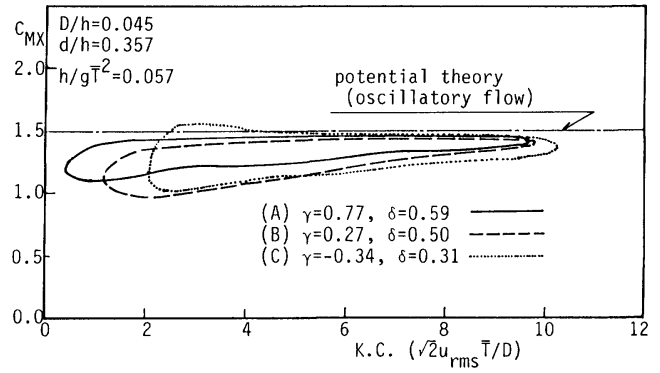

図一4 $C_{M X}$ と K.C. 数の関係に及ぼす $\gamma$ の効果

剝離のある範囲でも慣性力係数は波高増大過程の波の値 の方が波高減少過程の波の值よりも大きくなり，ループ 状の分布となることが認められる．規則波の慣性力係数 については, 剝離が起こり, 渦が放出されるようになる と慣性力係数が小さくなる傾向のあることが報告されて いる1). 二成分波の場合は波高増大過程よりも波高減少 過程の方が先行波の渦は大きく，その影響も大きい。 そ のため, 波高減少過程の波の慣性力係数が波高増大過程 の值よりも小さくなるものと考えられる.

a-2） $\gamma$ と $\delta$ の効果

無次元加速度と無次元流速の最大値の差, あるいは渦 の影響の大きさの差は，波高の相関が小さく，また，波 高の変動の大きい方が，すなわち波高の変化の大きい方 が大きくなる．波高の変動係数 $\delta$ が， $C_{M X}$ に及ぼす影 響については，本実験では，二成分波を生起させるとき

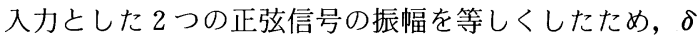
の值は $0.4 \sim 0.5$ の間の場合が多く, $\gamma$ ほど詳細な論議 はできないものの， $\delta$ の值の大きい方が， $C_{M x}$ の值の差 は大きくなることが認められた．図一4は， $C_{M X}$ に及ぼ す $\gamma$ の影響を調べた一例を示したものである，同図に は, $D / h, d / h$ と $h / g \bar{T}^{2}$ が同じ值で, $R e$ 数の範囲も ほぼ等しく, $\gamma$ が異なる 3 つの波に対する $C_{M X}$ の分布 の概略のみが示されている．同図からも認められるよう に， $\gamma$ が小さくなるほど $C_{M X}$ の分布はより上下方向に

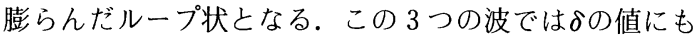


差があるが，慣性力係数の值は $\gamma$ が小さい方が，より 上下方向に膨らんだループ状の分布形状になると推察さ れる。これは，本論では図示しないが，K．C．数が大き く，抗力が卓越する場合でも同様である.

a-3) $D / h, h / g \bar{T}^{2}$ と $d / h$ の効果

規則波の $C_{M x}$ については，D/hと $h / g \bar{T}^{2}$ はほとん ぞ影響を及ぼさないことが報告されている の場合も，D/h は $C_{M X}$ にほとんご影響を及ぼさないこ とが確認された。しかし， $C_{M x}$ の值は $h / g \bar{T}^{2}$ の值の変 化により変動し，一例として図一5に示されるように， $h / g \bar{T}^{2}$ が小さいほぼ $C_{M X}$ の分布の幅が大きくなり，波 高増大過程と波高減少過程の值の差は大きくなることが 認められた。この原因の 1 つとして，成分波間の非線形 干渉が考えられる。

次に， $C_{M X}$ に及ぼす $d / h$ の効果であるが，限られた 実験の範囲内では， $d / h$ の大きい方が $C_{M X}$ は若干大き くなる傾向が認められた．これは，K.C. 数の範囲に多 少差異はあるものの,規則波に対する結果と同様である.

b) $C_{M Z}$ (鉛直方向の慣性力係数)

図一6に $C_{M Z}$ と K. C. 数 $\left(\sqrt{2} w_{\mathrm{rms}} \bar{T} / D\right)$ の関係の一 例を示す．図一2の場合と同様に， $C_{M Z}$ の概略を破線で 結んである.同図でも，波高増大過程，波高減少過程の 波の定義は，既述の水平方向の流速と加速度を使って 行ったが，鉛直方向の流速と加速度を用いても，波高増 大過程では流速の方が加速度よりも相対的に大きくな

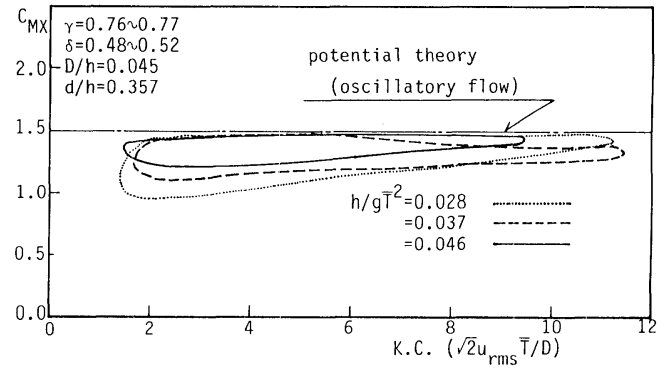

図一 $5 C_{M X}$ と K.C. 数の関係に及ぼす $h / g \bar{T}^{2}$ の効果

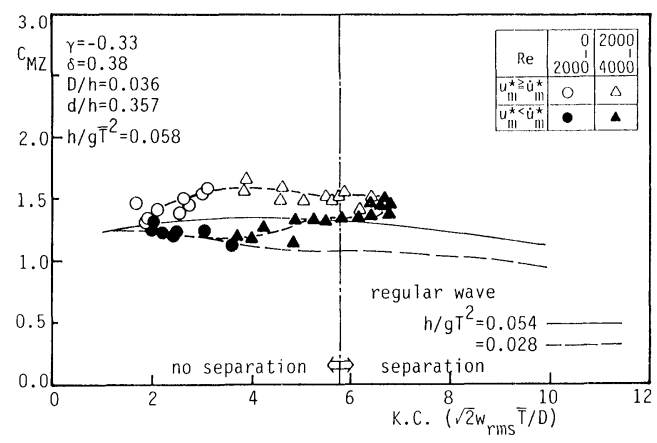

図一6 $C_{H Z}$ と K. C. 数の関係
り，波高減少過程では，流速よりも加速度の方が相対的

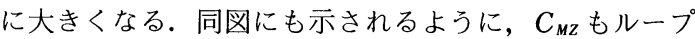
状の分布亡なり，同一の K. C. 数に対して $C_{M z}$ は $2 \supset$ の值をとることが認められた。 そして， $C_{M Z}$ の大きい方 の値は波高増大過程の波の値であること， $\gamma$ が小さいほ

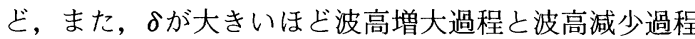
の $C_{M Z}$ の差が大きくなることなど， $C_{M X}$ と同様な特性 が認められた。 $h / g \bar{T}^{2}, D / h$ と $d / h$ の効果についても $C_{M X}$ の場合之非常に良く似ていることが確認された。た だし， $C_{M Z}$ の場合は，全体的にループの上側と下側の值 の差は $C_{M X}$ の場合よりも大きくなる傾向がある。これ は，球の上下で水平方向流速が異なるため，鉛直方向に 力が作用し，その影響が現われたことが原因の 1 つとし て考えることができる。

以上の結果より，慣性力係数 $C_{M X}, C_{M Z}$ は $\gamma$ が小さく なり，また， $\delta$ が大きくなって引き続く波高の差が大き くなると，慣性力係数は波の時系列の影響を受け，波高 の増大過程と減少過程で值が異なるようになることが指 摘できる.

\section{（2）抗力係数の特性}

a) $C_{D X}$ (波進行方向の抗力係数 $)$

a-1) K. C. 数と $R e$ 数の効果

図一7(a)，（b）にそれぞれ慣性力が卓越する場合と 抗力が卓越する場合の $C_{D X}$ と K. C. 数の関係の典型的 な例を示す．同図にも剥離が始まる K. C. 数の值が示 してある．また，図中の点線は，抗力の慣性力に対する 割合が $5 \%$ であることを示す． $C_{D X}$ の一般的な傾向と しては，図一7からも認められるように，剝離のある範 囲ではほぼ一定值をとり，その值は 0.5 に近い。しかし, 㓦離のない範囲では $\mathrm{K} . \mathrm{C}$. 数の減少に伴い $C_{D X}$ は減少 し，その減少の仕方は，図一7からはあまり明瞭ではな いが， $h / g \bar{T}^{2}$ の大きい方が顕著であり，規則波の場合 と同様な傾向が認められた。

ところで，図一7にも示されているように，K.C. 数 が 5 程度以下の範囲で， $C_{D X}$ が負の值になる場合の多い ことが認められた。この原因は，次のように考えること ができる. K. C. 数が小さく, 渦の放出もない範囲では, 前節で既述したように，Morison 式中の抗力項に示さ れるような流速の 2 乗に比例する力とは発生機構の異な る力, すなわち水の粘性による摩擦力, 境界層の形成に 伴う力 ${ }^{6)}$ が抗力の主要な成分であると考えられる．流速 との間に位相差をもつこれらの力に，Morison 式をそ のまま適用したために，抗力係数が負の值になったもの と考えられる. しかし，K.C. 数が小さい範囲では，抗 力は慣性力に比してかなり小さいため, 本論では, 工学 的な簡便さという点に立ち, 波力算定式として Morison 式を適用している．K. C. 数が小さい範囲，特に慣 


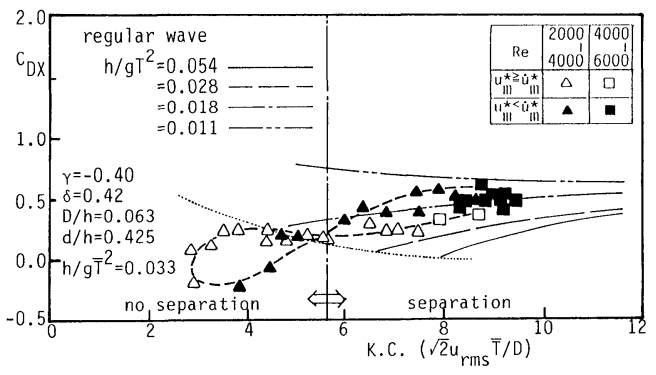

（a） 慣性力が卓越する場合

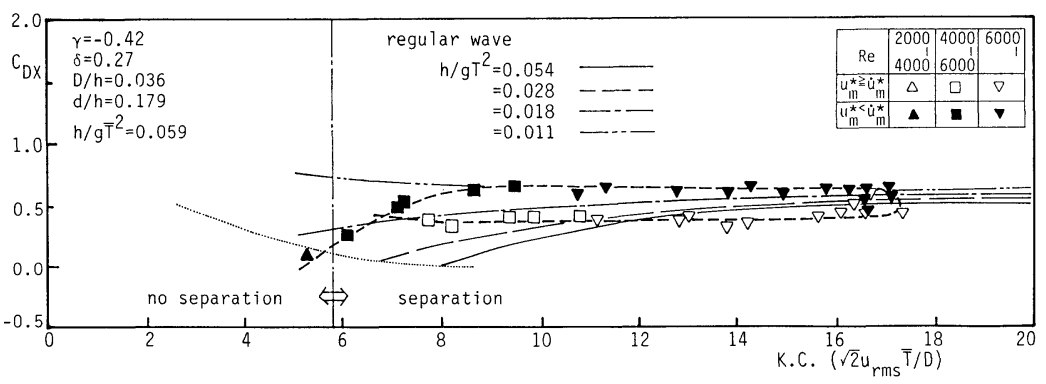

（b）抗力が卓越する場合

図一7 $C_{D X}$ と K. C. 数の関係

性力が卓越する領域の抗力の発生機構，および表示式に ついては，別途，稿を改めて報告する予定である.

波高増大過程と波高減少過程での抗力係数の差は, 慣 性力係数の場合とは異なり, 剝離の有無によって恋化す る.すなわち，剝離のある場合では波高増大過程の波の 值の方が波高減少過程の波の值より小さくなる傾向があ るのに対して, 剝離のない場合には両者の大小関係は逆 転し，図一7(a) の実験值を結んだ破線に示されるよう な斜め $\infty$ の字のような分布形状となる。また，㓦離の ない範囲では, $R e$ 数の小さい方が， $C_{D X}$ の差は大きく なる．図一7(b) では，剝離のない波の值が少ないため に, 抗力係数はループ状の分布となっている. 両図より， 剝離のない範囲では，波高増大過程の波の值の方が波高 減少過程の值より大きくなることから，この範囲の抗力 の支配的な成分であると考えられる摩擦力，境界層の形 成に伴う抗力は波高増大過程の方が大きくなると推察さ れる．また，剝離が起こり，渦が放出されるようになる と, 渦の発生に伴う圧力の非対称性による力が支配的に なるが，波高減少過程では，先行波で形成される渦は大 きく，その影響も大きいために波高減少過程の $C_{D X}$ が 大きくなったものと考えられる.

\section{a-2） $\gamma$ と $\delta$ の効果}

$C_{D X}$ は，慣性力係数に比べてばらつきが大きく，波高 増大過程と波高減少過程における差は, 慣性力係数の場 合ほど明暸ではないが，波高の相関係数 $\gamma$ のさい方

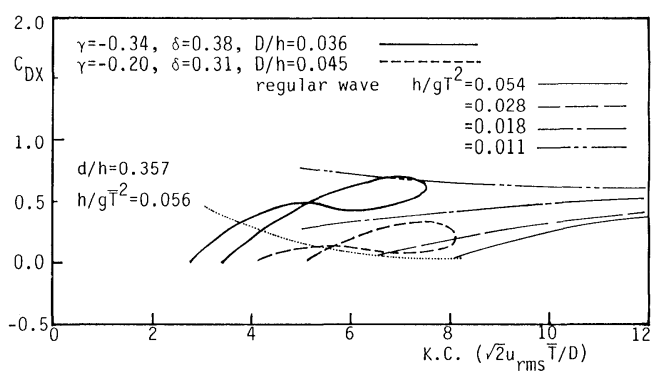

図一8 $C_{D X}$ と K. C. 数の関係に及ぼす $\boldsymbol{D} / \boldsymbol{h}$ の効果

が大きくなる傾向が認められたままた，変動係数 $\delta$ の 大きい方が， $C_{D X}$ のばらつきは大きくなるものの，波高 増大過程と波高減少過程の差は大きくなることが確かめ られた。

a-3) $D / h, h / g \bar{T}^{2}$ と $d / h$ の効果

図一8は, $\gamma$ が同じ範囲 $\left((\mathrm{C})\right.$ 領域) で, $h / g \bar{T}^{2}$ の 値も等しく, Re 数の範囲もほぼ等しい二成分波で $D / h$ が異なる場合の $C_{D X}$ の比較を行ったものである。 $D / h$ $=0.045$ に対する値と $D / h=0.036$ に対する値を比較す るとわかるように， $D / h$ が大きい方が抗力係数は小さ くなる傾向がある．この原因の 1 つとして，水深が浅く なったことによる波の非線形性が大きくなったことが考 えられる。

$h / g \bar{T}^{2}$ が及ぼす効果については，a-1) で既述したよ 
うに, K. C. 数の減少に伴う $C_{D X}$ の減少の割合が, 規則 波の場合亡同様, $h / g \bar{T}^{2}$ の大きい方が影著であり，同 じ K. C. 数の值に対しては, $h / g \bar{T}^{2}$ の大きい方が $C_{D X}$ は小さくなる．また， $C_{D X}$ に及ばす $d / h$ の影響につい ては， $C_{M X}$ の場合ほど明瞭ではないが， $d / h$ の小さい 方が $C_{D X}$ は小さくなる傾向がある，すなわち，規則波 の抗力係数に対して著者らが指摘したように ${ }^{1)}$, 球体周 りの水粒子の運動の軌跡が円に近くなる方が $C_{D X}$ は小 さくなる.

図一7，8には，規則波に対する抗力係数の值も示さ れている. 二成分波の $C_{D X}$ と規則波の值を比較すると, 図一7，8 加もわかるように，二成分波の値は規則波 の値に比べて多少大きくなっていることが認められた. 球体周りの流況の可視化の結果によると二成分波の流況 は規則波のものと基本的にはよく似ているが，波一周期 内の時間変化に差のあることが確かめられた．本実験で は, 球体周りの流況は回転パターン1)のみが観測されて いるが，規則波の場合は，この回転パターンの流況は， 流れの方向は変化するものの波一周期内の流況の本質的 な時間変化はほとんよ゙なく，安定した状態が保たれる ${ }^{1)}$. これに対して，二成分波の場合は渦系の大きさ，あるい は，剝離域の大きさなどがその回転とともに変化するこ とが確かめられた，すなわち，二成分波の波別解析波之 同じ波高，周期をもつ規則波であっても，抗力の発生機 構である剝離による圧力の非対称性，球表面での摩擦力 に差があることになる．この差が波力係数の差に現われ たものと考えられる.

b) $C_{D Z}$ (鉛直方向の抗力係数)

紙面の都合上，本論では図示できないが，K.C. 数の 值に伴う $C_{D Z}$ の変化の全体的な傾向，および他の支配 無次元量の影響は， $C_{D x}$ とよく似ていることが確かめら れた。しかし， $C_{D Z}$ の方が $C_{D X}$ よりも若干值が小さくな るようである。これには， $F_{X}$ と $F_{Z}$ に含まれる揚力の 差が原因の 1 つとして挙げられる.

ところで, 不規則波の抗力係数 $C_{D X}, C_{D Z}$ は, 非常に ばらつきが大きいことが報告されている ${ }^{2)}$ が，二成分波 に対する結果から推論すると, 波の時系列特性の及ぼす 影響が不規則波の場合は波別解析波ごとに異なるため， 抗力係数が大きくばらつくものと考えられる. 不規則波 の慣性力係数 $C_{M X}, C_{M Z}$ も抗力係数ほゼではないが, や はりばらつきは大きい22. これに対しても抗力係数と同 様のことが指摘できよう。

\section{（3）無次元最大波力の特性}

\section{a) $F_{x}^{*}$ (波進行方向の無次元最大波力)}

規則波の最大波力は，流れの剝離がない場合は波高に 比例し，剥離が起こると波高の 2 乗に比例するようにな ることが著者らによって明らかにされている ${ }^{1)}$ 二成分
波に対する無次元最大波力と K. C. 数の関係の例を図一 9(a)，(b) に示す．なお，本研究では，無次元最大波 力の表示法は, Morison 式の抗力項との関連も考慮し て $x$ 方向については, $F_{X_{m}} / \rho\left(u \sqrt{u^{2}+w^{2}}\right)_{m} D^{2}$ (以下, $F_{x}^{*}$ と略記する $), z$ 方向については, $F_{Z_{m}} / \rho(w$ $\left.\sqrt{u^{2}+w^{2}}\right)_{m} D^{2}$ (以下, $F_{Z}^{*}$ と略記する) とした ${ }^{1)}$. 二成 分波の無次元最大波力も規則波の值と同様に，剥離のな い範囲では K. C. 数の増加に伴い減少し，その減少の 傾きはー1に非常に近いこ上，また，永離がある範囲で は一定值に近づく傾向が認められた（図一9参照).

図一9にも示されるように，K.C. 数が小さく剥離が ない範囲では， $F_{x}^{*} は ，$ 慣性力係数の場合之同様に，そ の分布形状はループ状になり，波高増大過程と波高減少 過程では值が大きく異なることがわかる．また， $\gamma$ の小 さい方が，波高増大過程と波高減少過程の值の差が大き くなる傾向が涊められた。しかし，F $F_{x}^{*} は$ 波高増大過程 の值の方が波高減少過程の值よりも小さくなる傾向があ り, 慣性力係数と逆の結果となり, 一見奇異にみえる. これは次の理由による.

規則波の場合は，流速，加速度ともに，その振幅は時 間的に変化しないが，二成分波の場合はそれぞれの振幅 は時間的に変化する. K. C. 数が小さく慣性力が支配的 な場合は，図一1にも示されるように，波力の位相は加 速度の位相に近い. しかし, 波力の最大值を無次元化す るのは，加速度よりも位相が遅れた流速である．波高增 大過程では，流速の振幅は時間の進行とともに增大する ため，波力を無次元化する流速の值は，波力が最大にな

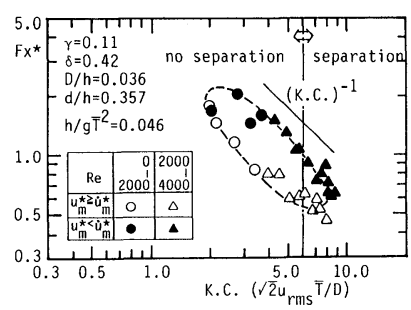

（a）慣性力が卓越する場合

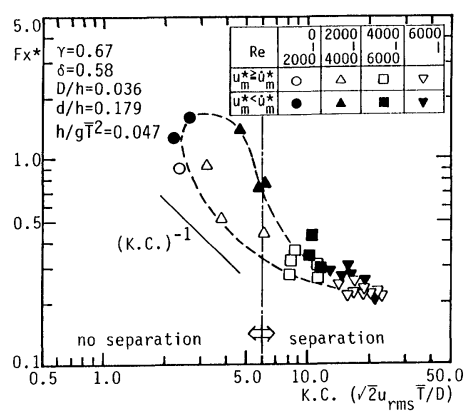

（b）抗力が卓越する場合

图一9 F $\quad F_{x}^{*}$ と K. C. 数の関係 
る瞬間の振幅よりも大きくなる，逆に，波高減少過程で は，流速の振幅は減少するため，波力が最大になる瞬間 の振幅よりも小さくなる．したがって，波高増大過程の 無次元最大波力は小さくなり，また，波高減少過程の無 次元最大波力は大きくなる．抗力が卓越し，波力の位相 と波力を無次元化する流速の位相が近くなると，無次元 最大波力が, 波高増大過程で小さくなり, 波高減少過程 で大きくなることはなく，一定值に近づく．以上の結果 より，無次元最大波力の特性を議論するうえで，波の時 系列の影響を考慮する必要のあることが指摘できる.

b) $F_{z}^{*}$ (鉛直方向の無次元最大波力)

図一10 は，K. C. 数が小さく慣性力が卓越する場合 の $z$ 方向の無次元最大波力之 K. C. 数の関係の一例を 示したものである. $z$ 方向の無次元最大波力 $F_{z}^{*}$ につい ても，慣性力が卓越する場合には，波高増大過程の值は 波高減少過程の值よりも小さく，ループ状の分布をする こと，また，本論では図示していないが，K.C. 数が大 きくなり，抗力が卓越するようになると，無次元最大波 力は一定值に近づくなよ゙， $x$ 方向の無次元最大波力 $F_{x}^{*}$ と同様の傾向が認められた。

なお，最大波力の絶対值は，波の周期が短く，深海波 に近い場合は, $F_{X_{\max }}$ と $F_{Z_{\max }}$ の值はほとんど同じである が, 波の周期が長くなるに従って, $F_{Z_{\max }}$ は $F_{X_{\max }}$ に比べ て小さくなることを付記しておく.

\section{（4）波力の予測}

波別解析波ごとに波力の時間波形を計算し，それを連 続的につなぐことにより，1つの波の時系列記録に対す る波力の時間波形の計算は可能である. しかし, この手 法によると計算時間は長くなるため，すべての波別解析 波で波力係数を一定として計算できる方が便利である.

次に，3.（2）で記述した（ii）の手法によって得ら れた波力係数を使って計算された波力と実測波力の時間 波形を比較した一例を図一11に示す．同図からも認め られるように，計算值は実測値と概略等しいが，波力の 極大値，極小值に着目すると，計算波力と実測波力の間 で若干差が認められ，大きい場合で $20 \%$ 程度にもなり， 無視できない大きさとなる．これは，波別解析波ごとに 異なる波力係数を 1 つの值で代表させたためであり，波

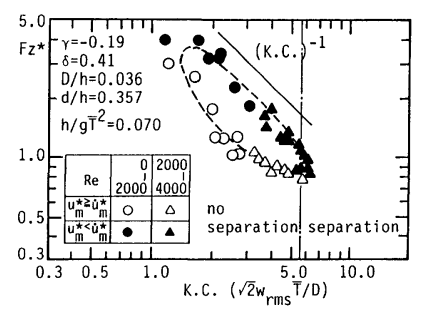

図一10 $\quad F_{2}^{*}$ と K. C. 数の関係

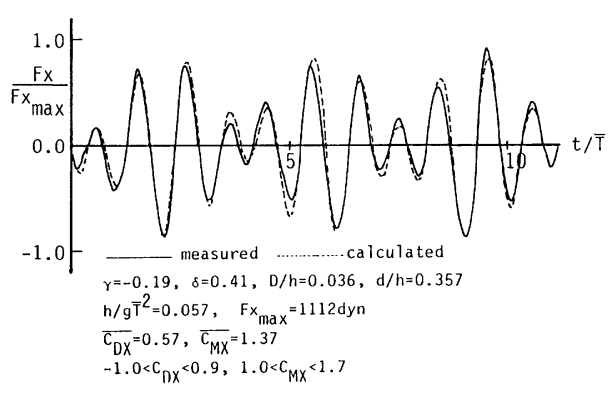

図一11 計算波力と実測波力の時間波形の比較 ( $F_{X}$ の場合)

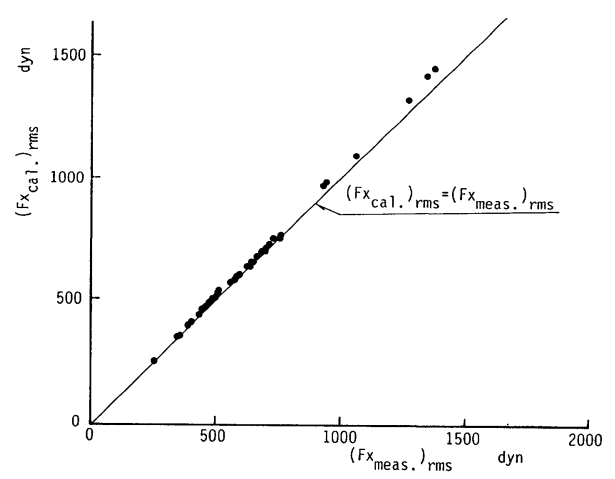

図一12 計算波力と実測波力の $\mathrm{rms}$ 值の比較 $\left(\left(F_{X_{\mathrm{cal}} .}\right)_{\mathrm{rms}}\right.$ は $x$ 方向の計算波力の $\mathrm{rms}$ 值, $\left(F_{X_{\text {meas }}}\right)_{\mathrm{rms}}$ は $x$ 方向の実測波力の $\mathrm{rms}$ 值 $)$

高増大過程と波高減少過程で值が異なる波別解析波の波 力係数を 1 つの值で代表させることの困難さを示してい る.したがって，二成分波の波力の時間波形を正確に算 定するためには，計算量は多くなるが波別解析法を使う 必要があることが指摘できる．しかし，波力係数をすべ ての波別解析波で一定として計算された波力について は，rms 值に代表されるような，平均的な值は，図一12 に示されるように,精度良く予測することが可能である.

（ii）の手法で計算した波力係数を，波別解析波の波 力係数と比較すると, 慣性力係数の值は, 波高増大過程 と波高減少過程の值のほぼ平均值であることが認められ た．また，抗力係数については，図一7(b) に示される ように, 抗力が卓越し, 抗力係数がほぼ一定值となる K. C. 数が大きい波に対しては, 慣性力係数と同様に, 波高増大過程と波高減少過程のほぼ平均的な值になる が, 図一7(a) に示されるように, 慣性力が支配的な波で, 抗力係数が, K. C. 数とともに変化するような場合は, 1 つの波の時系列の中でも，抗力の割合が大きくなる K. C. 数が大きい範囲の抗力係数の平均値に近いことが 認められた。

また，規則波の波力係数の值との関係については，次 


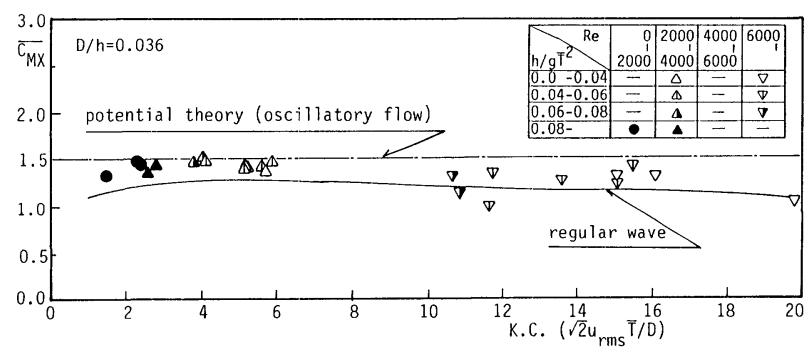

図一13 $\overline{C_{M X}}$ と K. C. 数の関係

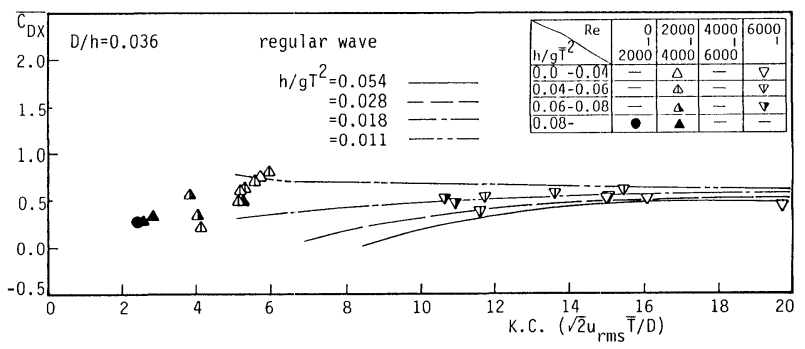

図一14 $\overline{C_{D X}}$ と K. C. 数の関係

のような結果が得られた。慣性力係数 $\overline{C_{M X}}$ は，図一13 に示すように, K. C. 数が 6 以下の範囲で若干二成分波 の值の方が規則波の值よりも大きいものの，全体的には 規則波の値とほぼ同じ值になる.また，抗力係数 $\overline{C_{D X}}$ は, 図一14 に示すように, K. C. 数が $5 \sim 6$ 以下の範囲で二 成分波と規則波の值の差が若干大きいが，K. C. 数が 10 以上の範囲では，両者はほぼ等しいとみなすことが できる. K. C. 数が 5 以下の範囲では，慣性力が支配的 であるため，作用波力を慣性力のみとしてもかなり精度 良く表現し得る。したがって，実際の波力の計算におい ては，規則波の波力係数の值を使うことにより，二成分 波の波力の $\mathrm{rms}$ 值といった平均的な值を予測すること は可能である．本論では，紙面の都合上， $x$ 方向波力に 対する值のみを示したが, $z$ 方向波力についても同様に， 規則波に対する波力係数を使うことにより，波力の $\mathrm{rms}$ 值は精度良く計算できることが確認できた。

\section{5. 結 論}

本論で得られた結果を以下に要約する.

（1）波高が増大する過程（波高増大過程）の波の慣 性力係数は, 波高が減少する過程（波高減少過程）の波 の值に比べて大きくなり，同じ K. C. 数の值に対して, 2 つの値をとる.

（2）波高増大過程と波高減少過程の慣性力係数の差
は, 相関係数 $\gamma$ の小さい方が大きくなり，また， 変動係数 $\delta$ の大きい方が大きくなる傾向があ る.

（３）抗力係数は, 剥離のある範囲ではほぼ 一定値となるが, 剥離のない範囲では K. C. 数の值によって変化し,規則波の場合と同様に, $h / g \bar{T}^{2}$ の大きい方が值は小さくなる.

（4）抗力係数は, 剝離のある範囲では, 波 高減少過程の波の值の方が大きく，また，剝離 のない範囲では，波高増大過程の波の值の方が 小さくなる傾向がある.

（5）波力の最大值は，慣性力が卓越する場 合は，波高増大過程の方が波高減少過程の波の 值よりも大きくなる．しかし，流速の 2 乗で無 次元表示すると，波高増大過程の無次元最大波 力は，波高減少過程の值よりも小さくなる.

（6）二成分波の波力の $\mathrm{rms}$ 值などの平均 量は，波力係数をすべての波で一定であると仮 定し，規則波に対する波力係数を使えば，精度

良く算定できる．しかし，波力の時間波形を正 確に計算するためには波別解析法を使う必要がある.

\section{参 考 文 献}

1）岩田好一朗・水谷法美：没水球体に作用する波力の特性 に関する研究，土木学会論文集，第 405 号 / II -11, pp. 215 224, 1989.

2) Iwata, K., Mizutani, N. and Kasai, S. : Irregular wave forces acting on a submerged sphere, Coastal Eng. Japan, Vol. 30, No.1, pp. 117 130, 1987.

3) Morison, J.R., O'Brien, M.P., Johnson, J.W. and Schaaf, S. A. : The force exerted by surface wave on piles, Tech. Pub. No. 284, Petroleum Trans., AIME, Vol. 189, pp. 149 154, 1950.

4) Keulegan, G. H. and Carpenter, L. H. : Forces on cylinders and plates in an oscillating fluid, J. Res. Nat. Bur. Stand., Vol.60, No. 5, pp. 423 440, 1958.

5）河野二夫：球形物体の波による鉛直方向の流体力一重複 波一, 琉球大学理工学部紀要, pp. 37〜46, 1974.

6）石田啓・田村賢一：非剝離流および対称渦対状態にお ける波動場の円柱の抗力係数，土木学会論文集，第 393 号/ II -9, pp. 121 130, 1988.

7）岩垣雄一・椹木 亨: 海岸工学, 共立出版, 463 p., 1979.

8）岩垣雄一・石田 啓：波動により円柱上に発達する 3 次 元境界層について, 第 21 回海岸工学講演会論文集, pp. 1 6, 1974 .

(1988.10.20 • 受付) 